\title{
Rethinking the connections between Turkey's "Western" identity versus Islam
}

\section{Ümit Cizre Sakallioğlu}

To cite this article: Ümit Cizre Sakallioğlu (1998) Rethinking the connections between Turkey's "Western" identity versus Islam, Critique: Journal for Critical Studies of the Middle East, 7:12, 3-18, DOI: $10.1080 / 10669929808720118$

To link to this article: https://doi.org/10.1080/10669929808720118

册 Published online: 11 Apr 2007.

Submit your article to this journal

Џlll Article views: 179

Citing articles: 1 View citing articles $\widetilde{ }$ 


\title{
$+$
}

\section{Rethinking the Connections Between Turkey's "Western" Identity Versus Islam}

\author{
Ümit Cére Sakallioglu
}

On December 13, 1995, Turkey and the European Union (EU) initialed an historic accord to establish deeper economic ties through the establishment of a customs union that lifted all tariff barriers between the two sides. Based on the Ankara Agreement of 1963, it was a considerable step on the rocky path of Turkey's intended integration with Europe. Nevertheless, it is questionable whether commonality ever will be reached between Turkey and the EU. The issue became acute after the collapse of the Soviet Union in the wake of the political and cultural identity crisis which resulted for Europe and Turkey. The end of the cold war has unleashed a search for a new mission, vision, and identity for Europe. The Soviet Union's demise has ended the bipolar security system and caused new non-military security problems, including the issue of establishing a new European integration and identity. With the rise of regional and ethnic conflicts within her borders and among her neigbors, Turkey has begun to address an identity crisis as well. The Kurdish problem and the tide of political Islam have raised fundamental questions about the basic assumptions of the Turkish national state and its identity. Confronted with the post cold war forces of fragmentation threatening to undermine her unity and Western-oriented national identity, Turkish elites have been propelled toward securing a place within Europe.

This quest for identity is interwoven with another issue, that of defining politically the frontiers of Europe. Occasionally, some policy analysts advocate that European identity should not be defined through barriers against the outside world but rather by a process linked to integration and democratization. ${ }^{1}$ The

1. Karsten D. Voigt, "Europe's New Challenges Need Strategic and Long-Term Answers," Trialogue 46: The Trilateral Commission's 1993 Washington Meeting, pp.55-57.

Ümit Cïre Sakallioğlu is associate professor of political science, Bilkent University, Ankara, Turkey. 
prevalent view in the EU, however, is that the East European countries and Turkey are "headache zones" whose identity lack clarity. However, the integration of the central and east European and Baltic countries into the EU structure is seen in a more positive light than is the integration of Turkey. Indeed, since the signing of the Customs Agreement, Turkey has not been included with the eleven names comprising east European countries and Greek Cypriot state on the EU's list of candidates for eventual membership. ${ }^{2}$ Since the early 1990s, arguments have been made to the effect that East European governments are expected to make progress toward democracy and marketization once they have been accepted into the EU. ${ }^{3}$ Some argue that despite political, economic and social disparities between these countries and the EU, overall stability and security in Europe will benefit when this area becomes a part of the European system. ${ }^{4}$

\section{A "Headache Zone" Country}

Turkey's status as an associate member of the EU (and its predecessors, the European Economic Community [EEC] and the European Community [EC]) since 1963 notwithstanding, the EU is reluctant to apply the same criterion to Turkey. Instead of full membership, Turkey only is offered a customs union based on the formula, "connection without commitment." ${ }^{n}$ This double standard is defended by referring to Turkey's tarnished record regarding democracy, human rights and the rule of law. In the pro-democracy climate of the post cold war era, it is argued that these deficiencies are an impediment to full inclusion. ${ }^{6}$. In time, the EU has added other themes to their list of conditions regarding their unwillingness to embrace Turkey, the most important being the turbulent relations of Turkey with Greece and Turkish objection to the accession talks the EU holds with the Greek Cypriot Republic. Turkey believes that the EU uses the prospective entry of the Greek part as leverage to pressure it to persuade Turkish Cypriot

Reprinted by a special issue of Global Issues in Transition 5 (November 1993): 141.

2. “AB, Bugün Git Yarn Da Gelme”. (The EU, Not Today, Don't Come Tomorrow Either), Milliyet, 17 July 1997.

3. Ronald D. Asmus, et. al., "Building a New Nato," Foreign Affairs (September-October 1993): 28-30.

4. Carl Bildt, "Importance of Nordic Influence in EU," Financial Times, 22 November 1994.

5. Semih Vaner, "İzolasyon Kampanyası” (The Isolation Campaign), Yeni Yüzyıl, 16 January 1995.

6. Visits and statements by the EU officials to that effect abound. The one by Hans van der Broek, the commissioner responsible for EU's foreign affairs is a typical expression of the above three complaints. See "AB Yine Restleşti" (The EU Challenges Again), Hürriyet, 23 July 1997. 
community leader Rauf Denktaş to assent to a federated state of Cyprus. ${ }^{7}$

Further complicating the issue of Turkish membership in the EU is the fact that both sides ascribe differing implications to the customs union. Turkey sees it as more than simply an agreement on customs. Its view derives from the Turkish political elite's belief that, after 150 years of waiting, Turkey is on the brink of becoming a part of modern Europe. For Turkey's political elite, EU membership has acquired new urgency because global and internal changes within the country during the last two decades have made the cultural and political fault lines between secular nationalists and Islamists obvious. As a result, the protagonists of full integration into Europe see this as the solution to all internal problems, including coping with fundamentalist Islam: "To integrate with Europe and to enter the EU for this purpose is a real salvation for Turkey. It is the most important result of our 200 year old endeavour to Westernize." 8 The underlying fact is that the prospect of political integration with Europe, even at an unknown future date, has been viewed as a source of strength for the secular and democratic forces in Turkey.

For both sides, the question of Turkey's entry into Europe is not only tied to economic and foreign policy considerations. Nor does the condition that Turkey must be more democratic reflect the whole reality, if this were so, the rather uncritical acceptance of the Turkish military regime (1980-83) by European leaders would be inexplicable. The European perception that Turkey's cultural identity is non-European, or simply of a lesser degree, lies at the heart of the problem: "Today, people from Southern Europe are still considered to be lesser Europeans. As for the Turks and non-Europeans, they clearly fall on the other side of the invisible line that encircles and defines Europe proper." Empirical evidence for this outlook was provided at a recent meeting in September 1997 between the German Chancellor Helmut Kohl and the Turkish Prime Minister Mesut Yllmaz, who agreed to Kohl's demand that Turkey's full entry into the EU is conditional on Turkish nationals being barred from circulating freely in Europe. ${ }^{10}$ This obstruction, which is a full "right" for citizens of other members of the EU, no doubt, is spurred by a defensive reaction on the part of the EU to avoid importing Turkey's unemployment problem into the hearts of Europe's metropoles. This EU position, nevertheless, throws open the real issues

7. See the statement by the current Prime Minister of Turkey, Mesut Yilmaz, "AB Uğruna Ne Kıbrıs'tan Ne De Ege'den Vazgeçeriz” (We Would Give Up Neither Cyprus Nor the Aegean Sea for the Sake of EU), Hürriyet, 25 October 1997.

8. Oktay Ekşi, "Battyla Bütünleşmeye Karşı Çıkan Mı Var?" (Is There Anybody Opposing Integration with the West?), Hürriyet, 3 March 1995.

9. Reşat Kasaba, "By Compass and Sword," MERIP, no. 178 (September-October 1992): 10.

10. "Istediğimizi Aldık" (We Got What We Wanted), Hürriyet, 1 October 1997. 
underlining the current debate in Europe about a European identity vis-à-vis a Muslim country, as well as European concern about the "structure of Turkey's population."11

"Cultural correctness" thus has become a prerequisite for Turkey's entry into European ranks. For example, in his 1993 "Clash of Civilizations?" article, Samuel Huntington described Turkey as having a "torn country syndrome." In a very real sense, Huntington echoes the Western anxiety about its own identity in a revived notion of the West as Christian civilization and Turkey as a part of Islamic civilization. In this view, the Westernized aspects of Turkey's culture are not considered as merits but as negative forces operating at the elite level and dividing it from the essentially Islamic outlook of the masses.

\begin{abstract}
These are torn countries. Their leaders typically wish to pursue a bandwagoning strategy and to make their countries members of the West, but the history, culture and traditions of their countries are non-Western. The most obvious and prototypical torn country is Turkey. The late twentieth-century leaders of Turkey have followed in the Atatürk tradition and defined Turkey as a modern, secular, Western nation-state. They allied Turkey with the West in NATO and in the Gulf War; they applied for membership in the European Community. At the same time, however, elements in Turkish society have supported an Islamic revival and have argued that Turkey is basically a Middle Eastern Muslim society. In addition, while the elite of Turkey has defined Turkey as a Western society, the elite of the West refuses to accept Turkey as such. Turkey will not become a member of the European Community, and the real reason, as President Özal said, "is that we are Muslim and they are Christian and they don't say that." Having rejected Mecca, and then being rejected by Brussels, where does Turkey look? Tashkent may be the answer. ${ }^{12}$
\end{abstract}

It is not the task here to critique or refute Huntington's view. Nor is it the objective to debate whether the self-interest of the EU would be served better by integrating Turkey politically, or by marginalizing it. Rather, the objective is to understand better the ongoing problematic relationship between political and cultural identities in a "headache zone country." However, the conceptual premises of the arguments that will be examined also reveal much about the structural, moral, and ideological underpinnings of the torn country syndrome.

\title{
Religion-State Dialectic
}

Contrary to what Huntington claims, the overriding antagonism in Turkish politics is not grounded in a simple dichotomy between the ruling elite and the masses, or Western forces and Islamic elements. Such a presumption, as found in early modernization and structuralist theories, fails to explain the essential nature and structure of traditional social forms, which are influenced not only by

11. Altan Öymen, "Neyimiz Farkl1?" (What Is Our Difference?), Milliyet, 9 November 1997.

12. Samuel Huntington, "The Clash of Civilizations?," Foreign Affairs, vol. 72, no. 3 (Summer 1993): 42. 
external (imperialism) but also by the state's domestic "political" stratagem. In order to understand Turkish politics, the dichotomy between Islam and modernity, or elite and mass or center and periphery, must be blurred. There is, instead, a contingent relationship between identity and politics of integration with the West that is part of a larger pattern of state and societal relationships.

The role played by Islam as a constituent of Turkish identity cannot be equated with a persisting cultural pattern of resisting, reacting to or subverting Western-oriented social change (Westernization), which has been equated with modernization. Since the establishment of the Republic of Turkey in 1923, there has been a dialectical interplay between the state and Islam, causing each to trigger responses in the other so as to preclude the possibility of Islam becoming a simple reaction against Westernization, operating independently from political and social determiners. Understanding this relationship requires an appreciation for history. The roots of Republican commitment to Westernization lay far back in the Ottoman Empire, which initialed modernizing reforms aimed at strengthening the central state in the early nineteenth century. This process of secular modernization "was an unsettled issue during the Ottoman period, as opinion was divided between those who equated modernization with Westernization (the Westernists) and those who opted for accepting Western technology while preserving Islamic institutions and culture (the Islamists). ${ }^{13} \mathrm{By}$ collapsing Westernization into modernization, the Republican ruling elite abandoned the compromising stand of the Ottomans and made Westernization a top priority. Nevertheless, since the early days of the Republic, this Ottoman historical legacy continued to shape Turkish identity, with Islam being the chief marker. ${ }^{14}$ The new "national identity" that the republican elite constructed would stand a good chance of legitimizing itself in the eyes of the population if it had made Islam the cultural norm of its official discourse. However, the Turkish nation-state was based on a total repudiation of the past cosmological outlook of the Ottoman Empire, an outlook embedded in Islam. The new legitimizing ethos became the nationalist principles that aimed at a total transformation of the cultural values of the "Republican man" in such a way that he would support Westernization.

In addition to nationalism, secularism became the second principle of legitimation of the state. It meant the disestablishment of Islam as the state religion and making politics independent of religious considerations. Establishing a positive Western-like self, however, was difficult unless the negative and "significant other"-Islam-was present. Thus, promotion of a European-like

13. Binnaz Toprak, "The Religious Right," in Irvin Schick and Ertuğrul Ahmet Tonak, eds., Turkey in Transition (New York and London: Oxford University Press, 1987), p. 222.

14. Ibid., p. 221. 
Turkish identity historically has involved an open recognition of Islam as a crucial element of Turkish identity. The problem then, was one of constructing a modern identity that would match the stronger tradition and older institutions of Islam. To achieve this, the Republican elite revived the Ottoman state tradition of including the highest functionaries of Islam, the ulema, within the structures of the state and created a similar agency called the Directorate of Religious Affairs (Diyanet İşleri Başkanlığı). "Establishment Islam," thus, became an instrument for articulating a national community in line with a comprehensive system of radical reforms; ${ }^{15}$ the government abolished the sultanate, the caliphate, the office of Şeyh-ül-İslam (the highest religious authority in the Ottoman Empire), and the shari'a courts. Between 1925 and 1930, Sufi religious orders were outlawed, and Swiss civil codes, Italian penal codes, and the Latin alphabet were adopted. In 1928 , the second article of the 1924 constitution, which designated Islam as the state religion, was annulled, and the principle of secularism was inserted into the constitution in 1937.

As a result of the interplay between religion and the Republican state, the recent tide of political Islam in Turkey cannot be understood in terms of the Westernization project having gone bankrupt but only as a contingent relationship existing between secular nationalist politics and Islam. Analysis must move away from portraying Western facets of Turkish identity and Islam as two polar opposites that have only two modalities of interaction, where the failure of the former politics leads to the rise of the latter force.

\section{Convergence Between a Western Political Identity \& Choice for Brussels}

As a predominantly Muslim country desiring to be close to Europe, Turkey provides a testing ground for the dialectical tension between an Islamic identity and a national one. This twin identity ideally is based on being part of a Western alliance. Until the West's emphasis on democratization began in the 1980s, Republican politics depicted Westernization both as the "goal" of entering into the ranks of Western civilization and a "model" for change and reform.

\section{The Role of the State}

Three basic factors have structured a national identity congruent with a EU, or Brussels-centered, hemisphere: the domination of a state-oriented nationalist discourse; the global changes since the 1980s; and the incoherence of the theory of nationalism. The most important characteristics of official Turkish nationalism have been its radical commitment to emulating and matching Europe and the fragile synthesis it has formed with democracy. Not unlike Huntington's view,

15. Bernard Lewis, The Emergence of Modern Turkey (London, Oxford, New York: Oxford University Press, Second Edition, 1968), pp. 262-83. 
it sees society composed of two mutually exclusive camps: the modern and the Islamic (traditionalist). In the early Republic, nationalism was not the ideology of a non-existent bourgeoisie or of any other strata. It was created by the state-building cadres, the military officers and the Westernized civilian bureaucrats. Their choice of Western and modernist principles for Turkish nationalism was neither accidental nor incoherent. These principles were deemed essential for establishing a modern state based on capitalism and for sustaining the political hegemony of the bureaucracy. Modernity understood as Westernization was connected with economic prosperity and a strong state.

In defining socially a homogenous nation, national identity was used to diminish the existing cosmology based on religion. Islam was portrayed as an inferior cultural marker and pushed out of the public realm, with hopes that its importance also would recede in the private sphere. ${ }^{16}$ The tension between Islam and Westernization at the identity-formation level stemmed from the official definition of the nation which excluded non-standard elements in terms of religion, language and ethnicity. This strategy produced a sharp contrast between a depressing view of the Ottoman past and a modern optimism for the present.

A left-right ideological spectrum in Turkish politics first appeared in the post World War II era. The original pro-Western and pro-modern discourse of the state was shared by the majority of political platforms and ideologies. ${ }^{17}$ The fundamental reason for this was the state-dependent features of the Turkish left, right and center; even though they may have claimed to represent either traditional or periphery politics. With political platforms born from splits within the central bureaucratic elite, both their leadership structure and support bases were linked organically to state largesse through etatist and populist policies. The state's cold war anti-communist ideology and the rising Turkish bourgeoisie's demand for relative freedom also contributed to the popularity of Western and modernist thought.

In the 1990 s, the only two ideological positions that could qualify for any anti-Western stand are some marginal shades of political Islam and conservative nationalism. These positions each offer their own priorities in search for cultural authenticity to command legitimacy. An analysis of post-1980 developments shows that both platforms support ambiguous constitutive categories for a Turkish identity. They often have simply reduced the problem to an untenable segregation between keeping authentic Turkish culture and borrowing science and technology from the West. Unlike the Islamists, who equate authentic culture with Islam, the

16. Şerif Mardin, "Religion and Secularism in Turkey," in Ali Kazancigil and Ergun Özbudun, eds., Atatürk, the Founder of a Modern State (London: C. Hurst, 1981), pp. 215-16.

17. Çağlar Keyder, "The Dilemma of Cultural Identity on the Margin of Europe," Review, vol. XVI, no. 1 (Winter 1993): 26-27. 
conservative nationalists lean on a combination of elements from conservativism, ethnic Turkishness, and Islam. ${ }^{18}$ Only the minority radical Islamist groups opt for an openly anti-Western and anti-modernist posture. In the coalition government formed between the pro-Islamic Welfare Party (Refah Partisi) and the center-right True Path Party (Doğru Yol Partisi) in June 1996 (it lasted one year), Welfare leader, Necmettin Erbakan who became the prime minister, made anti-Western overtures by flirting with Iran, Iraq, and Libya. He also tried to form a bloc of Muslim countries as an alternative to the EU. ${ }^{19}$ However, even before the coalition government resigned under heavy pressure from the secular civil and military elite and the organized sections of the civil society, it showed its readiness to compromise with the secular traditions in the Turkish state system, including the historical commitment of the state to continue to struggle for full inclusion in Europe, despite the negative signals coming from the EU. Realities of Turkey's electoral politics, which in the 1995 elections provided a 21.3 percent vote for Welfare, reinforces the belief that "Turkey has not gone Islamist ... the vast majority of Turkish voters chose parties that divide over many issues but not over the secular character of the state. Even half of the Refah Party's voters prefer to describe themselves in polls as secular. ${ }^{n 20}$

\section{Post-1980 Impetus}

Endorsement of Western-originated values and norms by the majority of ideological positions in Turkish society is also the work of the post-1980 world order. The end of the cold war gave rise to two contradictory developments. First, the West's victory against communism led to the increased importance of secularism and market-oriented democracy in the country. The influx of ideas on individual rights, civilianization, pluralism, equality of minorities, women's rights and consumer rights supplied the ingredients for "a new conception of political identity based on being 'European' ${ }^{21}$ and a socially diverse and pluralistic form of modernization. "This sense of being modern is very central to Turkish political identity, ${ }^{n 22}$ as it contends that admission to the EU ultimately will differentiate Turkey from its regional neighbors. On a global economic level, full membership in the EU would show that "much of the democratizing pressure felt

18. Ithan Tekeli, "Türk-İslam Sentezi Üzerine” (On Turkish-Islamic Synthesis), Bilim ve Sanat 77 (May 1987): 5-8.

19. Martin Kramer, "The Middle East, Old and New," Daedalus 126 (Spring 1997): 105.

20. Ibid.

21. Richard Falk, "Democratic Disguise: Post-Cold War Authoritarianism," in Phyllis Bennis and Michel Moushabeck, eds., Altered States (New York: Olive Branch Press, 1993), p. 22.

22. Ibid. 
by Turkey is related to the perceived economic advantages of EU membership."23

The second outcome of the democratizing impulse at the end of the cold war and the social uprooting caused by market reforms was political Islam. The Turkish center-right, which has been in power since 1983, has failed to cope with the structural and cultural dislocations of economic liberalization. This has contributed to the increasing appeal of the Welfare Party, whose political platform addresses this issue. Its rise, however, should not be seen as support at the mass level for Turkey to change its Western orientation to one based on Islamic maxims. ${ }^{24}$ Rather, it should be seen as a manifestation of a pervasive failure of Turkey's center-right in carrying out a much needed political and economic reform that would create a visible improvement in day-to-day living. ${ }^{25}$

It is true that Turkey's political Islam seems driven by the thought that "the main threat to religious faith is, in fact, the commodification of everyday life" 26 and the corrupting influence of transnational values that bring the problem of identity and culture to the forefront. Responding to the culture-oriented tone of the 1990s, the Welfare platform focuses on defining and sustaining the cultural-moral parameters of a Muslim Turk and freeing him from Western contamination. Sacrificed in this endeavor are concrete and coherent political and economic policies. By being committed more to a gradual, long-term cultural change, rather than to an alteration of the legal and socio-economic framework, the Welfare's Islam becomes "not political but cultural-populist Islam" ${ }^{27}$ as the policies followed by government demonstrated. Despite the Welfare's statements and moves to improve ties with Islamic countries, formulation of foreign policy was restricted by the National Security Council, and the party could not live up to its inflammatory campaign thetoric on critical issues. ${ }^{28}$ One constraint on its actions was the fact that the global idea of expanding freedoms and rights has captured the imagination of most elements of Turkish civil society. Civic groups have been positioned against the secular political authoritarianism of the past and

23. Ibid.

24. Ruşen Çakır, "Refah Çalıştı, Haketti Kazandı" (The Welfare Party Worked and Earned what They Won), Sabah, 12 April 1994.

25. Hakan Yavuz, "The Return of Islam? New Dynamics in State-Society Relations And the Role of Islam in Turkish Politics," Islamic World Report 1 [3] (1996): 79-86; Ruşen Çakır, "Bir Sistem Partisi Olarak Refah Partisi" (The Welfare Party as Part of the System), Birikim 81 (1996): 31-35.

26. Brian S. Turner, Orientalism, Postmodernism and Globalism (London and New York: Routledge, 1994), p. 9.

27. Ali Yaşar Sanbay, "Refah Partisinin Ardındaki Sosyo-Politik Dinamikler" (The Socio-Political Dynamics behind the Welfare Party), Türkiye Günlüğ̈ 27 (March-April 1994): 21.

28. Brian Brown, "Turkey Tilts Toward Iraq," The Wall Street Journal, 4 September 1996. 
did not welcome the idea of an Islamic political platform seen as anti-democratic and anti-freedom. Thus, defending against the political rise of Islam became yet another apparent advantage of full membership in the EU. Another contributing cause to Welfare's failure seems to be the ideological dilemma faced by an Islamic party operating within secular parameters: "How to make the message effective without succumbing to the logic of the dominant forms of power? Islamic history demonstrates that this was never resolved, even if compromises were worked out, often with impressive results."29

\section{Nationalism's Indeterminacy}

Western liberal scholars have difficulty defining the term "nation" since incompatible elements are used in its definition. ${ }^{30}$ Universal principles of individualism and libertarianism conflict with particular national characteristics (i.e., culture, religion, ethnicity) that at times hinder the development of democracy and capitalism. One way to explain this indeterminacy is to argue that there is a "Western" and "Eastern" form of nationalism. ${ }^{31}$ Depending on the circumstances, either a democratic or an organic concept of nationhood is emphasized. The political construction of a national identity, therefore, draws strength from "the profound dualism at the heart of every nationalism ... civic and ethnic elements," ${ }^{32}$ the latter including cultural identity markers, language, and tradition.

Not unlike this dual structure, Turkish nationalism contains two contrasting strands: traditional cultural elements, the "psychic core ... the protein of nationalism, ${ }^{33}$ and the modern component organized around citizenship with universal rights. It has been the possibility of combining a strong emphasis on the ethnic/vernacular dimension with a stress on the civic principle that explains the power and salience of the Republican drive to achieve a civilizational jump. An additional factor that accounted for the intensity of official commitment to adopt a European-like identity was Turkey's lack of a colonial past and the absence of a pointedly anti-imperialist discourse.

29. Charles Tripp, "Islam and the State in the Middle East," Ethnic Studies Report 13 (July 1995): 195.

30. Liah Greenfeld, Nationalism: Five Roads to Modernity (Cambridge: Cambridge University Press, 1992), p. 8.

31. The proponent of this typology was historian Hans Kuhn, The Idea of Nationalism (New York: MacMillan, 1944).

32. Anthony R. Smith, National Identity (London: Penguin, 1991), p. 13.

33. Dawa Norbu, Culture and the Politics of Third World Nationalism (London and New York: Routledge, 1992), p. 33. 


\section{Counter-pressures Against a Western-like Identity Westernization via Republicanism}

In his book on national identity, Anthony Smith contends that the content, if not the form, of Turkish national identity proves elusive. ${ }^{34}$ To the extent that national identity is a specific identity, generating a national identity is a synthetic effort $^{35}$ geared toward sustaining the political power of the ruling elite. Once again, the civic and traditional duality of national concepts adds to the problem, as does structural limitations in Turkey's case. From the outset, the construction of a modern national identity in Turkey became linked with the logic of catching up with the modern West. Modernity understood as Westernization was connected with economic development and a strengthened ability of the rulers to govern. Diversity and social pluralism were seen as obstacles to the emergence of a modern and strong state. To overcome any threat of diversity, Turkish nationalism put the values of unity and uniformity above achieving political parity with the West. The crucial point here is that in the embarrassing geography Turkey found itself, construction of a Western identity became part of the attempt to extract recognition as a nation "on par" with the West. This means that the politics of the Republic have been geared to the objective of "controlling Westernization" in such a way as to ease integration with the West on an equal footing.

However, since modernity also entails a discourse of democracy and the rights and equality of citizens, this controlled modernization had to be connected with some kind of model for democracy. On this level, Westernization was articulated with the powerful impact of Rousseau's conception of the Republic which stressed "the centrality of obligations and duties to the public realm ${ }^{\text {n6 }}$ and of "the supreme direction of the general will, the publicly generated conception of the common good. ${ }^{37}$ Until the relative political liberalization of the post-1980 era, the three most enduring strategies of domestic integration were populism, corporatism, and a doctrine of popular sovereignty. The first two principles have been used for limiting any potential societal conflict by denying legitimacy to class, regional, ethnic, sectarian, and gender differences. ${ }^{38}$ These two concepts created an understanding of democracy that refused competition, subordinated the citizen to the state power structure, and sacrificed the rights of the individual against those of the state. National will became the culmination of a political

34. Smith, National Identity, p. 104.

35. Greenfeld, Nationalism, p. 12.

36. David Held, Models of Democracy (Stanford: Stanford University Press, Second Edition, 1996), p. 56.

37. Ibid.

38. Ümit Cizre Sakallığlu, 'Labour and State in Turkey: 1960-80," Middle Eastern Studies, vol. 28, no.4 (October 1992): 712-28. 
legitimacy based on popular sovereignty. In contrast to the Western liberal tradition, Turkish democracy has not emphasized democratic legitimation through respect for the rule of law, civil society and constitutionality. Instead, in line with Republican thought, the ends of the state, perceived as the promotion of national integration and national unity, have held priority over the rights of the individual.

Apart from the concern to maintain political stability, another factor that provided the rationale for importing only selected items of democracy from the West was the model of capitalist development chosen by the Republic. This model was an insular project that drew its strength from a radical strategy of domestic integration and non-liberal norms. Until the 1980s, Turkish national identity was conceived more as an instrument for reinforcing economic independence, and in general capitalism, than a means for upholding the legal-political equality of a nation's Western model.

The evidence of the 1960s and 1970s shows that, despite the strong existence of this control dimension, Europeanization set in motion by the early Republican elite was neither a clandestine nor flimsy aspiration. When national capitalisms and their development models entered a crisis in the post cold war period, however, new articulations of national identity at cultural, political, and economic levels subsequently became necessary. The new articulations also meant restructuring the state-societal relationship, since the bureaucracy-dominated modernization formula with its economic autarchy had turned anachronic. Once old forms of maintaining social control had become discredited, new ones had to be found.

Pride in ethnic roots and Sunni Islam have been articulated into the definition of modern Turkish identity. The neo-conservative tone of international politics, revival of Islam, and the escalation of the Kurdish conflict since 1984 provide the impetus for this synthesis. Indeed, discourses of a long line of center-right politicians since 1980 have identified Turkishness with Western values, albeit on a superficial level, with the symbols of the flag, blood and sacrifice, patriotism, ezan (prayer), and Muslim morals. The statements and speeches of the leader of the True Path Party, Tansu Çiller, who was prime minister in a series of coalitions from 1993 to 1996, are prime examples of this discourse. ${ }^{39}$ Although, as a woman politician, she symbolized the strong pro-Western streak in Turkish politics, Ciller nevertheless initiated the uneasy power-sharing pact between the Islamic Welfare Party and her own basically secular party in 1996. Her motive was to escape from a series of parliamentary investigations into her wealth and other alleged dealings. Behind the veneer of complying with the imperatives of

39. DYP Genel Başanı ve Başbakan Tansu Ciller'in Konuşmaları: 19 Haziran - 5 Kasm 1993 (The Speeches of the True Path Party Leader and Prime Minister Tansu Çiller: June 19 - November 5, 1993), (Ankara: Başbakanlık Basım Merkezi, 1993), pp. 13, 62, 95. 
multi-party politics, Çiller's coalition strategy brought into the open the fragile synthesis between Turkey's Westernization and its shaky tradition of liberal democracy that is understood not as accountability and responsiveness to the public but only as holding elections.

Since the 1980s, as political Islam and Kurdish nationalism began to push for a new social consensus based on political and cultural differences, the state has moved toward reestablishing its legitimacy, less rooted in secular projects but more intent on articulating these cultural differences into its official discourse. For fear of national disintegration, the state's new tolerance for political Islam was not extended to the Kurdish political movement. The main reason that the Kurdish factor constitutes a source of counter-pressure against democratization is because the military policy towards the PKK (Kurdish Workers Party) presents no legitimacy problem for the state. By promoting a militant Turkish nationalism based on the familiar theme of territorial integrity and unity, the state makes doubly sure that the question lies beyond any politics of accommodation. There is widespread support for this official line of perceiving and managing the problem, even though many also support a democratic unitary state based on the code words of conciliation, tolerance, and genuine political pluralism organized around multi-ethnic, multi-lingual, and multi-ideological groups.

At one level, international pressure on Turkey to correct its human rights record on the Kurdish issue helps to feed into an anti-Western sentiment. This is related to public concern about the intentions of the United States to create a Kurdish state in northern Iraq, a development having a destabilizing influence on the territorial unity of the country. It is also thought that Turkey's unconditional support for the Western alliance in the persian Gulf War in 1991 did not pay off political dividends comparable to its advantageous strategic interests. The Bosnian policy of the West additionally has aggravated this rising feeling of anti-Westernism: "There is indeed something irritating, no matter how justified, about European lectures on human rights, when in Bosnia the Europeans themselves managed nothing better than diplomatic double talk. ${ }^{40}$

\section{The Strength of Seemingly Weakened Islam}

Turkey's increased emphasis since 1980 on prospective full membership in the EU raises the crucial question as to whether anti-Western and anti-integrationist sentiments among Turkish political Islamists pose a threat to the intended process. The issue gained fresh importance with Welfare's rise to power. The most important historical context providing insight on this issue is the introduction of secularism as the basis for a Westernized Turkish national

40. Soli Özel, "Of Not Being a Lone Wolf: Geography, Domestic Plays, and Turkish Foreign Policy in the Middle East," in Geoffrey Kemp and Janice Gross Stein, eds., Powder Keg in the Middle East (Lanham, Maryland: Roman and Littlefield, 1995), p. 185. 
identity at the onset of the republic. Reinforced by the state-structured tone of single-party (1923-46) and multi-party periods since then, secularism became the catalyst for a planned society made up of two opposing sectors. "A schism developed between those political factions which demanded a revival of religious values and those which defended the official laicism of the Turkish republic. ${ }^{n 41}$

Denying Islam an active role in the making of a modern national identity was problematic, however, due to the difficulties in adopting values directly opposite of the historically authentic ones. Moreover, the problem was based on the need to rely on the people's cultural identity as nationals and citizens to be the building blocks of the nation. In Benedict Anderson's terminology, the difficult task was making individuals come to "imagine" themselves a part of a nation, and identify themselves with the "imagined community" of Turkey, with no handover of older cultural meanings, the strongest one of which was being a Muslim. ${ }^{42}$

In coping with this dilemma, the republican strategy was to adopt an official double discourse. Islam was disestablished as the state religion while religious language was incorporated into the nationalist discourse, without making its conceptual grammar essentially Islamic. Islam was depicted as the inferior other in order to allow the diffusion of its antithesis into a Western self. By a process called "orientalization of the national identity," ${ }^{13}$ the regime incorporated religious aspects of prior cultural markers into the modern Turkish identity, with the hope of making the latter more acceptable. In promoting a Western identity, Islam was given an important role in order to minimize its propensity to obstruct the positivist-Westernist goals.

This strategy highlights the contingent nature between the politics of integration with the West and that of identity/culture. The relationship between the state and Islam has never been marked with a pure causality model, the state totally banishing Islam from the strategic field of politics or Islam overwhelming and defeating the state. Instead, in a series of complex and dynamic interactions, both sides try to outmaneuver the other by moving to legitimize their own language. Portrayal of the War of Independence (1919-1922) against the West and the Ottoman rulers as Jihad, or Holy War, can be considered one attempt to recruit Islamic platforms to be durable features of nationalist politics. Western norms and values also were promoted with a religious zeal in order for

41. Serif Mardin, "Cultural Issues in Relations between Turkey and Europe," in Ahmet Evin and Geoffrey Denton, eds., Turkey and the European Community (Opladen, Germany: Leske and Budrich, 1990), p. 21.

42. Benedict Anderson, Imagined Communities: Reflections on the Origin and Spread of Nationalism (London: Verso, 1983), pp. 12-19.

43. Bobby Said, "Sign O' Times: Kaffirs and Infidels Fighting the Ninth Crusade," in Ernesto Laclau, ed., The Making of Political Identities (London and New York: Verso, 1994), p. 271. 
nationalism to become a "secular religion." ${ }^{44}$ Islam was assigned the political function of checking and blocking communism in the cold war era and attacking social class as being "divisive of the Muslim community and the instrument of 'Godless communism'. "45 After the 1980 military intervention, which resulted in a restructuring of the state and society in line with neo-liberal ideas of economic liberalism, Islam initially was given unprecedented recognition by the military elite as a bulwark against communism and a substitute for class-based ideologies. Both military and political leaders after 1980 believed Islam could help create a socially disciplined and politically stable society ready to undergo the structural dislocations caused by the transition to popular capitalism and global patterns of life-styles. As the most common denominator between official nationalism and Islam, political conservatism has provided the synthesis between Kemalist Westernism and Islam within the Turkish right.

Although it may appear to be a revolutionary break with the traditional political management of Islam by the state, the Welfare Party's advent to power represents only another mode in the state-Islam relationship that has not changed in terms of the former's basic goals and strategies. The experience of the Welfare Party in government showed that it seemed more ready to mobilize Islamic values to "conserve" the existing system than to reject the established order by launching a campaign against corruption in the state, giving effective expressions to individual rights, fulfilling developmental and social functions of the state, and expanding the political sphere. Abdullah Gül, a leading policy-maker of the party and the close advisor of the leader, admits that they failed to resolve the corruption charges in the state system: "let alone 'do' anything, we had the mentality of preserving the institutions. ${ }^{46}$ Yet, according to the deputy leader of the party, Aydin Menderes, who is a name in his own right by virtue of being the son of former Prime Minister Adnan Menderes (1950-1960), "the secular alliance between the military, media and capital" to overthrow the Welfare-led coalition government was, in fact, a "transitional and unserious thing. ${ }^{47}$ The reason why this "counter-plan" succeeded so easily was "the absence of any effective project on the part of the Welfare Party directed toward transforming the system. ${ }^{\text {nd8 }}$ For Menderes, "Welfare came face to face with its own inadequacies .... This

44. George Harris, "Islam and the State in Modern Turkey," Middle East Review 11, no. 4 (Summer 1979): 21.

45. Feroz Ahmad, "Politics and Islam in Modern Turkey," Middle Eastern Studies 27 (January 1991): 12.

46. Ruşen Çakar and Kemal Can, "Basiretsizlik, Kifayetsizlik" (Lack of Insight, Lack of Adequacy), Milliyet, 18 August 1977.

47. Ruşen Çakır and Kemal Can, "Menderes: Refah Partisi Solcuyum Desin" (Menderes: Welfare Party Should Say that It Is Leftist), Milliyet, 19 August 1977.

48. Ibid. 
government was the test case not for fidelity to the cause but for the skill of governing. We knew what to say 'no' to, but not what to say 'yes' to. ${ }^{\text {"49 }}$

Today, Islam's response to Westernism is, then, to ensure that neither its discourse nor other markers of cultural authenticity are removed from the political sphere. Since promotion of Europeanness historically has involved an open recognition of Islam as a crucial element of national identity, this has caused a symbiosis-like interaction with Republican ideology, binding the fate of the two constituent principles of Turkish identity together. Just as the modernist-secular machinery has resorted to "orientalizing itself" in order to achieve control over Islam, political Islam has allowed itself to be tainted by elements of Western cosmology to which it was a reaction. Thus, even if we accept that there are no basic values of an undifferentiated Islam as a permanent feature of Turkish society, political Islam only can be understood within the framework of the secular order of the Turkish state and its Republican tradition of political power.

\section{Conclusion}

For other countries caught in the same dilemma, what is the salience of the Turkish model's containment of the problematic relationship between politics of identity and integration in a trans-cultural era? Perhaps the most relevant lesson is the sustainment of a complicated and contingent relationship with Islam. Secular modernist politics have maintained a position that defines the parameters of the dominant political discourse while enabling it to strike deep roots in the polity. Both ideologies have manufactured their own language, myths, and debate in relation to each other. However, nationalism with a Westernizing impulse has been more successful at constructing a sufficiently coherent and convincing "imagined" community with a power of attraction for its members. This is so despite the fact that "continuing the affinity with the West when the latter's own project of modernity seems to have run out of steam, and when a degree of justifiable anti-Westernism is rampant in non-Western lands, is a more difficult project to defend these days for Turkey's modernized elites. ${ }^{n 50}$

49. Ibid.

50. Özel, "Of Not Being a Lone Wolf," p. 38. 